10IKC-364

\title{
ZIRCON U-TH-PB-HE DOUBLE-DATING OF NORTH AUSTRALIAN DIAMOND FIELDS: ELLENDALE (WA), SEPPELT (WA) AND MERLIN (NT)
}

\author{
McInnes BIA ${ }^{1,2^{*}}$, Evans NJ ${ }^{1,2}$, Jourdan $F^{2}$, McDonald BJ ${ }^{1,2}$, Danišík, $\mathbf{M}^{2,3}$, Gorter, $\mathrm{JD}^{4}$ and Mayers $\mathrm{C}^{1,2}$ \\ ${ }^{1}$ CSIRO Earth Science and Resource Engineering, Perth, Australia \\ ${ }^{2} J o h n$ de Laeter Centre of Isotope Research, Applied Geology, Curtin University, Perth, Australia \\ ${ }^{3}$ The University of Waikato, Hamilton, New Zealand \\ ${ }^{4}$ Eni Australia Ltd, 226 Adelaide Terrace, Perth, WA, 6000; PO Box 6862, East Perth, WA 6892 \\ *Corresponding author: b.mcinnes@curtin.edu.au
}

Current diamond exploration strategy includes the search for kimberlite indicator minerals (KIMS) such as chromite, garnet and $\mathrm{Cr}$ diopside in stream sediments and soil samples. KIMS are, however, prone to chemical dissolution under tropical weathering conditions and, therefore, alternative approaches involving the chemical analysis of resistant minerals such as zircon would enhance exploration success in tropical countries such as Australia.

Zircon U-Th-Pb-He double-dating studies at the Ellendale (WA) and Merlin (NT) diamond fields (Figure 1) have demonstrated that zircon helium contents and radioosotopic ages can be geochemically linked to the process of kimberlite/ lamproite eruption, making it useful as a new diamond indicator mineral (McInnes et al., 2009).

At Ellendale, diamond-bearing olivine lamproite dykes and tuffs exclusively contain thermally reset xenocrystic zircon with a weighted average (U-Th)/He age of $20.6 \pm 2.8$ (Figure 2), recording the time of dyke emplacement. This result was verified by phlogopite ${ }^{40} \mathrm{Ar}-{ }^{39} \mathrm{Ar}$ dating, which confirmed an emplacementage of d"'22 Ma. The multiple lithological contacts exposed within the mined maar volcano provide a natural laboratory in which to study the effect of volcanic processes on U-Th- $\mathrm{Pb}-\mathrm{He}$ systematics.

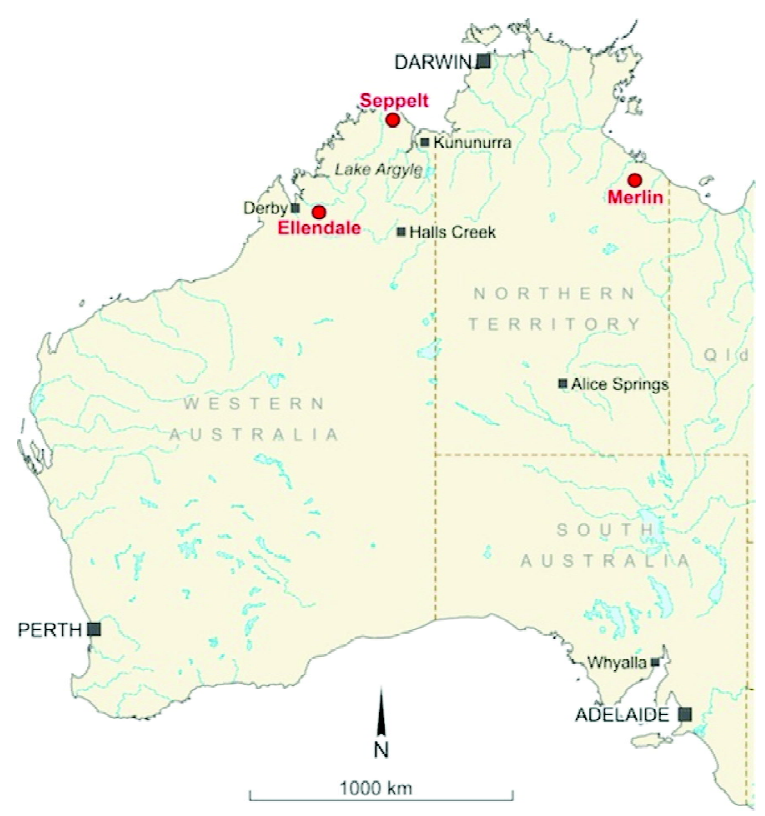

Figure 1. Location of Ellendale, Seppelt and Merlin sites.

A significant finding was that the Ellendale volcanic activity was an extremely short-lived and transient phenomenon that did not thermally reset the zircon (U-Th)/He systematics of the regional host country rocks, even within $1 \mathrm{~m}$ of dykecountry rock contacts (Figure 3).

Zircon from the Seppelt kimberlite field (Figure 1) in the North Kimberley Province (WA) 


\section{0 $^{\text {th }}$ International Kimberlite Conference, Bangalore - 2012}

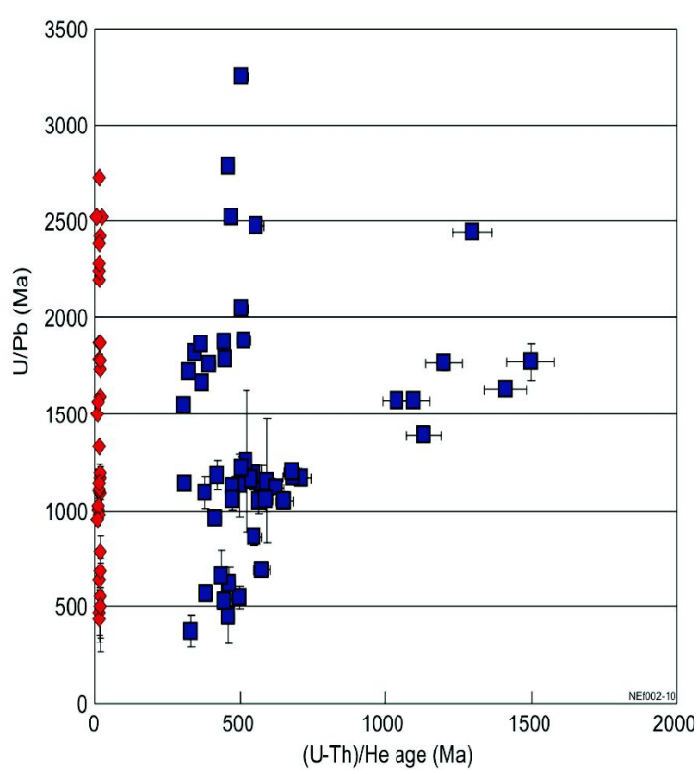

Figure 2. (U-Th)/He and $\mathrm{U} / \mathrm{Pb}$ age for double-dated zircon recovered from an olivine lamproite dyke (red diamonds) and host sedimentary rocks of the Grant and Fairfield Groups (blue squares) from the Ellendale 9 pipe. All samples display a range of $\mathrm{U} / \mathrm{Pb}$ ages whereas the country rocks also show a range of $(\mathrm{U}-\mathrm{Th}) / \mathrm{He}$ ages. However, the lamproitic zircon all return (U-Th)/He ages in the 18-22 Ma range, indicated that the helium ages were reset to that of the emplacement age as determined by phlogopite ${ }^{40} \mathrm{Ar}$ r ${ }^{39} \mathrm{Ar}$ dating (this study) and previous workers (Jaques et al., 1986). Error bars are 2s.

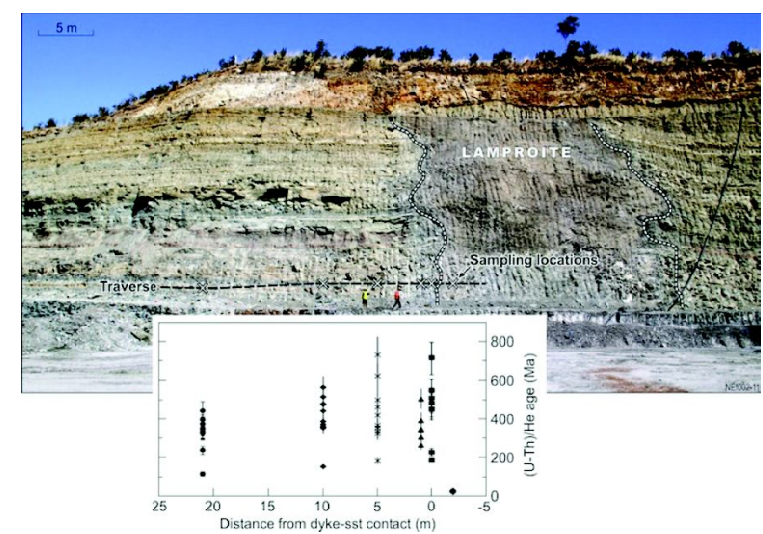

Figure 3. Main image is the NW face of the western pit of the Ellendale E9 pipe showing an olivine lamproite dyke intruded into country rock sediments of the Grant Group. Helium ages were determined from zircon extracted from rock samples collected from the dyke and adjacent sedimentary rocks at regular intervals (marked with an ' $x$ '). Inset graph shows range of ages obtained for samples from the lamproite dyke ( $n=30$, all plot as one point at $\sim 20 \mathrm{Ma})$, and samples at increasing distance from the contact. Note that only the lamproite zircon ages have been reset. returned two main (U-Th)/He age populations: (i) a broad Cambrian population reflecting the contamination of the kimberlite dyke by Pentecost Sandstone, and (ii) a minor yet significant Miocene population. The discovery that a single kimberlite dyke sample yielded four zircon grains with an average age of $\sim 25 \mathrm{Ma}$, was unexpected. The finding that two of these grains had extremely low $U$ and Th contents $(<2 \mathrm{ppm})$ is significant because such low concentrations are indicative of a mantle derivation (Ahrens et al., 1967; Belousova et al., 1998, 2002; Hoskin and Ireland, 2000; Page et al., 2007) and are expected only if zircon is either (i) a phenocryst of a kimberlite magma or (ii) a mantle xenocryst from the diamond source region. In either case, these two grains are the only zircon identified to have mantle signatures from the over 1200 zircon grains analysed in this study of Australian kimberlite and lamproite localities.

Additional evidence for relatively recent activity in the North Kimberley region comes from a zircon fission track study at the Skerring kimberlite pipe, located $40 \mathrm{~km}$ north of Seppelt. In that study, Pidgeon et al. (1989) reported:

"Zircons from the Skerring kimberlite are extremely low in $\mathrm{U}$ and a fission track age could not be determined due to paucity of spontaneous tracks."

These combined observations are consistent with a Miocene age for both the Seppelt and Skerring kimberlite eruptions. An Oligocene age of $\sim 25 \mathrm{Ma}$ for kimberlite activity in the North Kimberley is a potential link supporting the notion of Gorter et al. (2004) that northeasterly motion of the Australian plate over a mantle hot spot was a trigger for Cenozoic alkalic magmatism, linking a submerged diatreme field discovered during oil exploration in the Timor Sea (Fohn) with diatreme activity associated with the Ellendale ( $\sim 22-20 \mathrm{Ma})$ and Noonkanbah ( $\sim 19 \mathrm{Ma})$ lamproite fields in the Western Kimberley. If correct, this hypothesis would suggest that the Timor Sea diatreme field would be of Oligocene age. Samples from the Fohn-1 exploration well were subjected to mineral 
separation and although zircon was not abundant, a sufficient amount of biotite was extracted for ${ }^{40} \mathrm{Ar} /{ }^{39} \mathrm{Ar}$ geochronology testing (Figure 4). A robust plateau ${ }^{40} \mathrm{Ar} /{ }^{39} \mathrm{Ar}$ age of $29.4 \pm 0.7 \mathrm{Ma}$ $(\mathrm{P}=0.99)$ for the Fohn diatreme sample supports the hot spot transit hypothesis of Gorter et al. (2004).

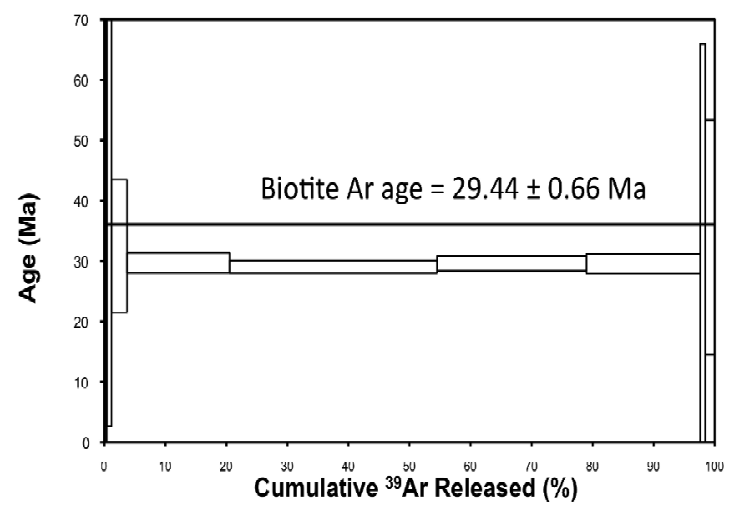

Figure 4. Biotite plateau ${ }^{40} \mathrm{Ar}^{39} \mathrm{Ar}$ age from a diatreme intersected during the 1994 drilling of the Fohn-1 exploration well in the Timor Sea.

The combined age-distance relationships between the Fohn $(\sim 30 \mathrm{Ma})$, Seppelt/Skerring $(\sim 25 \mathrm{Ma})$, Ellendale $(\sim 22-20 \mathrm{Ma})$ and Noonkanbah ( $\sim 19 \mathrm{Ma})$ sites are consistent with a NNE tracking of Australian plate motion across a mantle hot spot at a rate of $\sim 76 \mathrm{~mm} /$ year (Figure 5). This rate compares with the present rate of

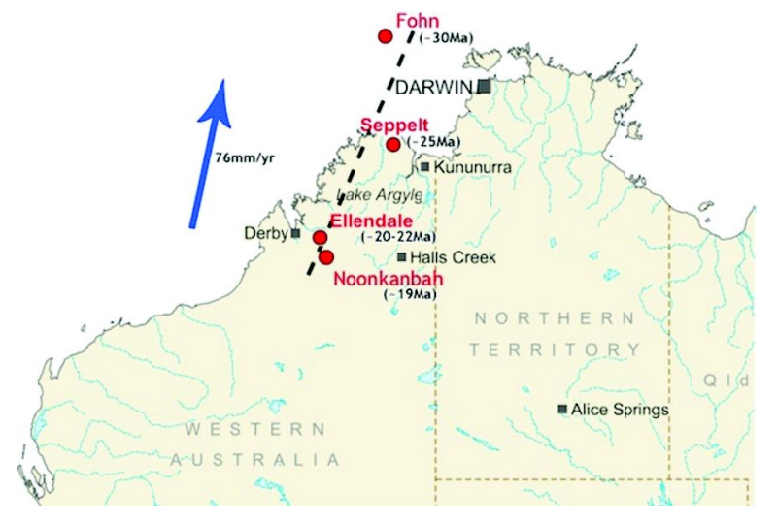

Figure 5. Distance-age relationships of Western Kimberley intrusives and the Fohn diatreme field (Timor Sea) support the supposition of Gorter et al. (2004) that the northeasterly motion of the Australian plate at $76 \mathrm{~mm} / \mathrm{yr}$ over a mantle hot spot was a trigger for Cenozoic alkalic magmatism. motion along the Australian-Asian plate and is within the range of estimates of plate motion of 50-78 mm/year (Wellman and McDougall, 1974).

The Merlin study confirmed the correlation between zircon (U-Th)/He ages ( $368 \pm 4 \mathrm{Ma})$ and previous geochronological studies of the kimberlite pipes (phlogopite $\mathrm{Rb} / \mathrm{Sr}$ age of $367 \pm 4$ Ma; Lee et al., 1998). Both U-Th-Pb-He doubledating and (U-Th)/He dating techniques allowed a differentiation between "hot" zircon grains associated with kimberlite facies lithologies and "cold" detrital zircon from the host country rocks (Bukalara Sandstone) (Fig 6).

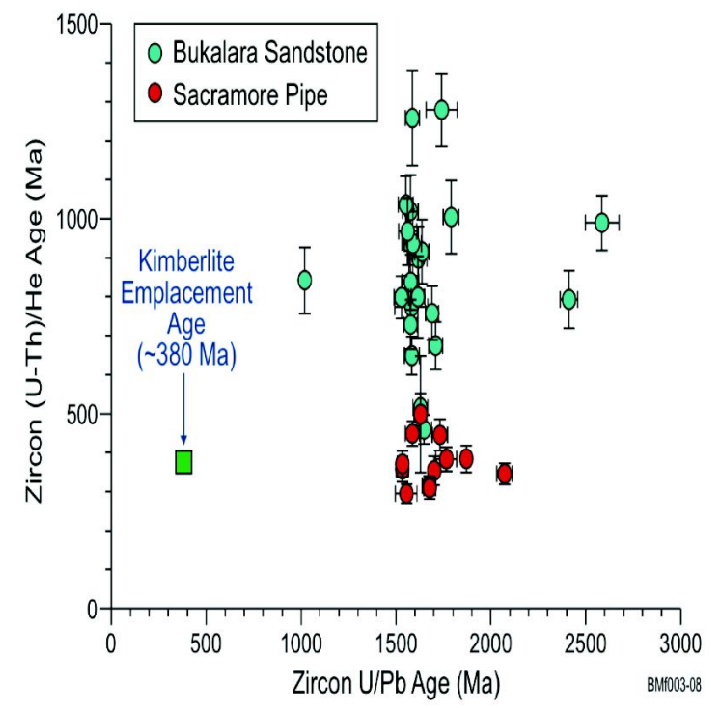

Figure 6. Zircon $\mathrm{U} / \mathrm{Pb}$ ages and $(\mathrm{U}-\mathrm{Th}) / \mathrm{He}$ ages for the Sacramore Pipe and Bukalara Sandstone. The mean (U-Th)/He age of the kimberlite zircon xenocrysts is identical to the previously determined emplacement age for the Merlin pipes (Lee et al., 1998). Similar to the Ellendale study, the consistently young (U-Th)/He ages of the "hot" kimberlite zircons distinguish them from "cold" crustal zircons in the surrounding host rocks.

Stream sediment samples of Merlin drainages were found to contain a bimodal population of zircon (U-Th)/He ages representing both the "hot" zircon from the pipes and "cold" zircon from the host Bukalara Sandstone (Figure 7). Detailed studies comparing the proportion of "hot" zircon recovered at each detrital sampling site and the presence of kimberlite indicator 


\section{$10^{\text {th }}$ International Kimberlite Conference, Bangalore - 2012}

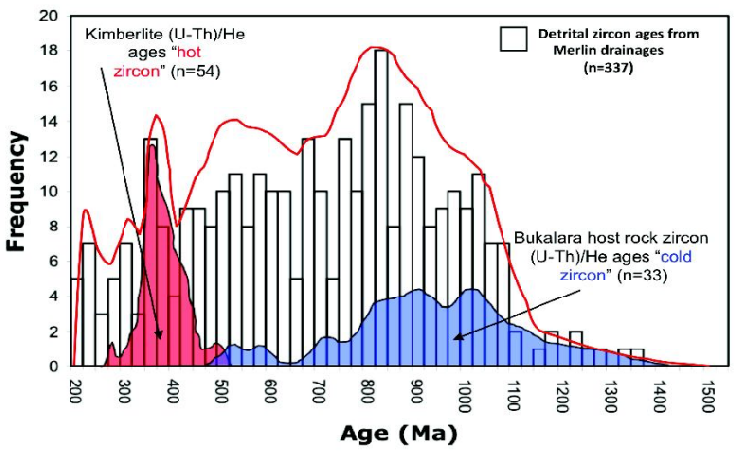

Figure 7. Frequency (U-Th)/He age distribution for the detrital, kimberlitic and regional host rock zircon from Merlin. The ages of zircon in the detrital population (red line and black blocks) pick up a younger, narrowly peaked population (200-450 Ma) corresponding to "hot zircons" from the Merlin pipes (emplaced $270 \mathrm{Ma}$ ) and an older, broadly peaked population (500-1400 Ma) corresponding to "cold zircons" from the Bukalara Sandstone host formation. Detrital zircons with (U-Th)/He ages less than $200 \mathrm{Ma}$ have no obvious source at this stage.

minerals (e.g., microdiamonds, chromite) yielded good corrrespondance (Figure 8). In an exploration context, the fact that "hot" zircon grains can be detected in samples weighing less than $1 \mathrm{~kg}$ is a significant logistical advantage over the currently utilised heavy mineral sampling techniques that require up to $100 \mathrm{x}$ more sample material.

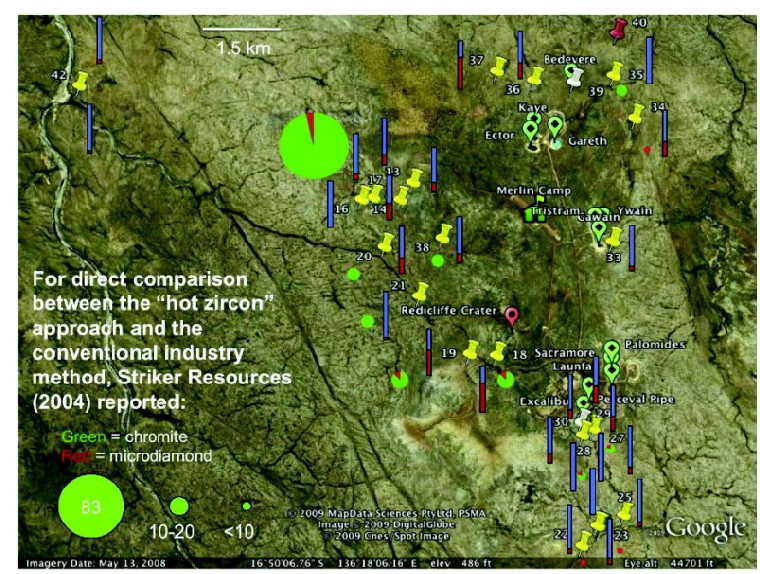

Figure 8. Correlation of microdiamond and chromite occurrences with "hot" zircon at Merlin. Red portion of the "thermometers" indicates the proportion of hot zircon at each sample location. The green circle with red pie-shaped sections shows the abundance of chromite and/or microdiamond that were recovered from each site. Note that the traditional KIM exploration samples were 100-1000 $\mathrm{kg}$ bulk samples while the samples for this study were d" $1.0 \mathrm{~kg}$. (Image source: Google Maps).
A challenge to the practical application of this technique in diamond exploration is the development of analytical techniques capable of cost effectively identifying "hot" zircons in stream sediment samples. One potential method of qualitative visual identification involves acid etching of zircon surfaces to reveal fission tracks, where "hot" zircon have low track densities relative to country rock zircon. An experimental fission track etching trial on "hot" and "cold" zircon from Ellendale showed promising results (Figure 9). After 4 hours etching in a $\mathrm{NaOH}-\mathrm{KOH}$ eutectic mixture at $210^{\circ} \mathrm{C}$ (Zaun and Wagner,
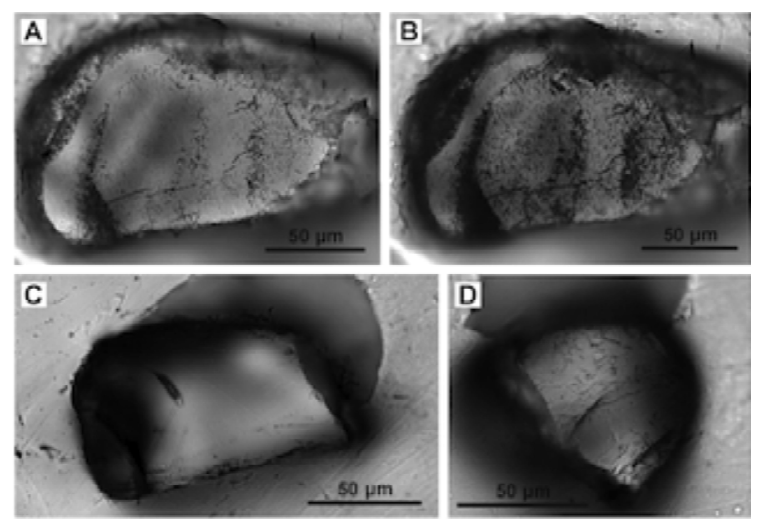

Figure 9. Grant Formation country rock zircon after 8 (A) and 13 hours (B) etch time; note strong zoning of uranium. C - kimberlitic zircon with an intact surface after 13 hours etch time; D - fission tracks in a kimberlitic zircon revealed after 25 hours etch time; note fairly homogeneous distribution of fission tracks.

1985), the majority of the host Grant Formation zircon turned black or was totally disintegrated, indicating significant accumulation of radiation damage or an advanced stage of metamictisation, however, no fission tracks were visible at this stage in either mount. After 8 hours, the rest of the Grant Formation zircon displayed high $U$ zones with properly etched fission tracks (Figure 9a). In contrast, all E9 lamproitic zircon still remained intact and showed no fission tracks. After 13 hours, previously visible high-U zones with visible fission tracks in the Grant Formation zircon became over-etched and properly etched fission tracks in low-U zones were revealed (Figure 9b). 


\section{0 $^{\text {th }}$ International Kimberlite Conference, Bangalore - 2012}

All zircon xenocrysts from the olivine lamproite remained unchanged (Figure 9c). The first fission tracks in the lamproitic zircon were revealed only after 25 hours (Figure 9d), at which point all Grant Formation zircon were totally disintegrated or over-etched. After 25 hours, the experiment was stopped, although the majority of E9 lamproitic zircon was still intact.

A more cost-effective approach useful for the exploration industry would involve construction of an automated helium assay instrument capable of measuring hundreds of detrital zircon grains per day. In early 2012, an integrated excimer laser ablation ICPMS + Alphachron ${ }^{\mathrm{TM}}$ helium extraction line will be installed in the John de Laeter Centre for Isotope Research at Curtin University. This instrument will allow in situ double dating of zircon and rapid helium assay for diamond exploration applications.

In summary, controlled studies at the Ellendale lamproite and Merlin kimberlite fields demonstrated a significant bimodal distribution of U-Th-Pb-He ages that discriminate between zircon from diamond-facies lithologies and barren country rock. Four zircon grains from diamondiferous kimberlite dykes from the Seppelt field with an average age of $\sim 25$ Ma may indicate a potential link between Oligocene alkalic volcanic activity in the Timor Sea (Fohn diatreme. field) and Miocene lamproite volcanism in the West Kimberley (Ellendale, Noonkanbah). Linear age-distance relationships between these sites are consistent with a hot spot trigger for kimberlite activity as the Kimberley Craton tracked in a NNE direction at a rate of $\sim 76 \mathrm{~mm} /$ year.

These case studies have each contributed to a better understanding of the thermal histories of Australian diamond deposits, and have demonstrated that zircon can be geochemically linked to the process of kimberlite/lamproite eruption, making it useful as a new diamond indicator mineral. This development could potentially contribute to a new wave of diamond exploration activity in areas where traditional kimberlite indicator minerals (garnet, Cr-diopside, olivine) are not present.

A challenge to the practical application of this technique in diamond exploration is the development of analytical techniques capable of cost-effectively identifying "hot" zircons in stream sediment samples. One potential method of qualitative visual identification involves acid etching of zircon surfaces to reveal fission tracks, where "hot" zircon would have low track densities relative to country rock zircon. An experimental fission track trial on "hot" and "cold" zircon from Ellendale showed promising results. A more industrial approach would involve construction of an automated helium assay instrument capable of measuring up to a thousand detrital zircon grains per day.

Acknowledgements: The authors would like to thank the Minerals and Energy Research Institute of Western Australia and M405 project sponsors (North Australian Diamonds Ltd., Venus Resources, Gem Minerals, Flinders Mines, Primary Industries and Resources South Australia, Northern Territory Geological Survey and the Geological Survey of Western Australia) for their support of this research. The advice and assistance provided during fieldwork by Tom Reddicliffe, Kerry Taylor, Wolf Marx and Dudley Corbett is most appreciated. Angelo Vartesi, Travis Naughton and Evan McInnes are thanked for drafting figures. Special thanks to Cameron Scadding and Allen Thomas (TSW Analytical, Perth) for assistance with ICP MS analysis and to Adam Frew for assistance with SHRIMP and ${ }^{40} \mathrm{Ar} /$ ${ }^{39} \mathrm{Ar}$ analysis.

\section{References:}

Ahrens, L.H., Cherry, R.D., Erlank, A.J., 1967. Observations on the Th-U relationship in zircons from granitic rocks and from kimberlites. Geochimica et Cosmochimica Acta 31, 2379-2387 


\section{0 $^{\text {th }}$ International Kimberlite Conference, Bangalore - 2012}

Belousova, E.A., Griffin, W.L., Pearson, N.J., 1998. Trace element composition and cathodoluminescence properties of southern African kimberlitic zircons. Mineralogical Magazine 62 (3), 355-366.

Belousova, E.A., Griffin, W.L., O’Reilly, S.Y., Fisher N.I., 2002. Igneous zircon: trace element composition as an indicator of source rock type. Contributions to Mineralology and Petrology 143, 602-622.

Gorter, J.D., Glikson, A.Y., Deighton, I., 2004. Diatremes in the Northern Bonaparte Basin? Implications for petroleum exploration. in: Ellis, G.K., Baillie, P.W. \& Munson, T.J. (Eds), 2004, Timor Sea Petroleum Geoscience, Proceedings of the Timor Sea Symposium, Darwin, Northern Territory, 19-20 June, 2003, Northern Territory Geological Survey Special Publication 1. ISBN 0 724570721

Hoskin, P.W.O., Ireland, T.R., 2000. Rare earth element chemistry of zircon and its use as a provenance indicator. Geology 28 (7), 627-630.

Jaques, A.L., Lewis, J.D. and Smith, C.B. 1986. The Kimberlites and Lamproites of Western Australia. Geological Survey of Western Australia Bulletin, 132. pp. 267.

Lee DC, Reddicliffe TH, Scott Smith BH, Taylor WR and Ward LM. 1998. Merlin diamondiferous kimberlite pipes. In: Berkman D. A. \& Mackenzie D. H. eds. Geology of Australian and Papua New
Guinean Mineral Deposits, pp. 461-464. The Australasian Institute of Mining and Metallurgy, Melbourne.

McInnes, B.I.A., Evans, N.J, McDonald, B.J., Kinny, P. and Jakimowicz, J. 2009. Application of zircon double-dating techniques in diamond exploration, Merlin kimberlite field, Northern Territory, Australia. Lithos, 112S, 592-599.

Page, F.Z., Fu, B., Kitaa, N., Fournellea, J., Spicuzza, M.J., Schulze, D.J., Vilgoen, F., Basei, M.A.S., Valley, J.W., 2007. Zircons from kimberlite: New insights from oxygen isotopes, trace elements, and $\mathrm{Ti}$ in zircon thermometry. Geochimica et Cosmochimica Acta 71 (15), 3887-3903.

Pidgeon R. T., Smith C. B. \& Fanning C. M. 1989. Kimberlite and lamproite emplacement ages in Western Australia. In: Ross J. R. ed. Kimberlites and Related Rocks. Volume 1: Their Composition, Occurrence, Origin and Emplacement. Proceedings of the Fourth International Kimberlite Conference, Perth, pp. 369-381. Geological Society of Australia Special Publication 14.

Wellman P and McDougall I. 1974. Cainozoic igneous activity in eastern Australia. Tectonophysics 23, 49-65.

Zaun and Wagner, 1985 P.E. Zaun and G.A. Wagner, Fission-track stability in zircons under geological conditions. Nucl. Tracks Radiat. Meas., 10 (1985), pp. 303-307. 